\title{
Cryopreservation - A Viable Alternative in Preparation for Use of Allografts in Knee Ligament Reconstruction
}

\author{
Alexandre C. Bitar et al. ${ }^{*}$ \\ Vita Institute \\ Brazil
}

\section{Introduction}

The use of allogenic tissues is growing in orthopedic practice, as well as the number of studies on methods for processing, sterilization and cryopreservation that interfere as little as possible with the original physiological properties of the tissues (Nutton et al., 1999).

In addition to bone tissue, other tissues of the locomotor system can be captured, processed and stored in tissue banks with the purpose of transplantation. Therefore a strict quality control must be implemented and set after discussions compiled by international organizations such as AATB e EATB.

The first report of the use of allografts in humans dates back to 1881. The first tissue bank of bone grafts was created in 1940 in the United States and the initial clinical results were published in 1942 by Inclan, 1942. Since then a series of regulations and studies has emerged relating to the use of grafts in orthopedic practice ${ }^{19}$. Currently, tendon allografts are used in knee surgeries, in elbow ligament reconstructions and in revisions of the acromioclavicular joint (Costic et al., 2004).

In our country we have few tissue banks. The tissue bank (BTME) from the Institute of Orthopedics and Traumatology (IOT), Hospital das Clínicas da Faculdade de Medicina da Universidade de Sao Paulo was the first and is the biggest bank in activity nowadays. It thas been in operation since 1999 and is governed by local legislation (Amatuzzi et al., 2000). With the restructuring of our service in 2005, we initiated a new technique aimed at the provision of the tendon with a well-structured quality program in line with other centers of excellence nationally and internationally. Today our service is provided by a series of tendons (tibial tendon, Achilles, patellar and peroneal) taken from different regions with very specific applications. Thus, we can then follow the technological trend in the use of

${ }^{*}$ Caio Oliveira D'Elia ${ }^{1}$, Antônio Guilherme P. Garofo' ${ }^{1}$, Wagner Castropil ${ }^{1}$, Luiz Augusto U. Santos ${ }^{2}$, Marco K. Demange², José Ricardo Pécora ${ }^{2}$ and Alberto T. Crocci $^{2}$

${ }^{1}$ Vita Institute, Brazil

2Universidade de São Paulo; Institute of Orthopedics and Traumatology, Hospital das Clinicas da Faculdade de Medicina da Universidade de São Paulo, SP, Brazil 
tissues already practiced in other global centers of excellence in orthopedics and traumatology.

In our medical service, Vita Institute (private use), and in the Institute of Orthopedics and Traumatology (public and private use), allografts are used mainly in knee surgeries, ACL reconstruction, multiple ligament reconstructions, ligament surgery in skeletally immature patients and with double bundle reconstruction.

\section{Importance of allografts in knee ligament reconstructions}

Grafts are used in various procedures in different branches of orthopedics, including ligament reconstruction. The literature shows the importance of the use of allografts in knee surgery, especially in revision surgeries, multiple ligament reconstructions and, more recently, surgery for primary reconstruction of the anterior cruciate ligament (ACL) in active patients and in those aged over 40 years (Marrale et al., 2007; Sherman \& Banffy, 2004). There have been at least 11 clinical studies comparing the use of auto and allografts in the reconstruction of the ACL (Chang et al., 2003; Marrale et al., 2007). Most of these show little difference between the two techniques with respect to long-term results. However, there has been few prospective randomized studies, and the comparison methods (scores), types of graft, as well as methods of preparing and fixing the graft are highly variable.

Furthermore, most studies use the patellar tendon graft; therefore, it may not be possible to generalize the conclusions of these studies to the flexor tendon. Some authors, such as Lawhorn and Howell, suggest the use of allografts without a bone plug because of the potential for slower incorporation of the bone due to immunogenicity and smaller crosssectional area of transplants with bone plugs (Lawhorn \& Howell, 2003). Recently, Sun et al. (2011) published a prospective randomized study comparing non-irradiated allograft with flexors autograft showing similar results between groups in terms of subjective clinical scores, goals, rate of return to sports and incidence of complications (Sun et al., 2011).

However, compared with autologous transplants, allografts do have some advantages. For example, they do not increase morbidity for the donor, they require a shorter surgery time, and they are available without restriction on size and morphology. In ligament reconstruction surgeries, the possibility exists of an immune response from the recipient tunnel enlargement, and delayed incorporation of the allograft (Marrale et al., 2007). The risk of disease transmission and the potential for immunogenicity are the major disadvantages of allografts, but these complications can be controlled (Albert et al., 2006; Barrios et al., 1994, Urabe et al., 2007).

\section{Controversy of methods of preparation of allografts}

The increased frequency of the use of allografts in traumato-orthopedics requires the adoption of storage techniques that interfere as little as possible in the quality of the parts (Vangsness et al., 2003). Allografts can be stored in different ways; they can be chilled in residential mechanical freezers at temperatures of $+2^{\circ} \mathrm{C}$ to $-4^{\circ} \mathrm{C}$ for up to five days. In freezers with temperatures of $-20^{\circ} \mathrm{C}$ to $-40^{\circ} \mathrm{C}$, they can be stored for up to six months ${ }^{14}$. At these temperatures, the enzymes present in the tissue are still active and can destroy the tissue. Therefore, storage periods of longer than a few months are not recommended. The methods of sterilization used at low temperatures are effective against fungi and do not seem to change 
the mechanical characteristics of the grafts. The period of 40 days chosen in our service for cryopreservation coincides with the period of incubation necessary for microbiological investigations for bacteria and fungi (Vangsness et al., 2003). The deep-freezing process enables storage for up to five years, and this is the method we use in our service ${ }^{19}$.

Many services prefer to carry out the manipulation of tissues under aseptic conditions from acquisition through clinical use, and the samples are discarded when microbiological assays show positive bacterial cultures (20 to 30\%) (Zimmerman et al., 1994). Sterilization methods, therefore, are not completely safe. They can alter the biomechanical characteristics of tissues or fail to penetrate tissue layers, resulting in the protection of microorganisms rather than their destruction. Irradiation with gamma rays is the most common method of sterilization (Sterling et al., 1995). However, to achieve safer sterilization in frozen tissues, high-dose irradiation is necessary, which can alter the biomechanical properties of the tissue in a dosedependent manner (Curran et al., 2004; Fideler et al., 1995).

Doses as low as 2 Mrad resulted in a statistically significant reduction in biomechanical properties, outcomes, or physical examination measures. Rappe et al. (2007) studied the effect of irradiation on clinical outcomes of ACL reconstruction, they found the irradiated group had an unacceptable higher rate of failure $33 \%$ ) than the non- irradiated group $(2.4 \%)$. Fideler et al. (1995) found that the dose of $2.5 \mathrm{Mrad}$, which was a dose commonly used by tissue banks for sterilization, was just bacteriocidal but ineffective in eliminating viruses such as human immunodeficiency virus (HIV) (Sterling et al., 1995). Doses of 3 to 4 Mrad were necessary to inactivate the virus. Grieb et al. also proved that lower levels of radiation may be inadequate to kill hepatitis and HIV viruses, with a dose of 5 Mrad being necessary (Grieb et al., 2006). When dosage is increased, its clinical implications increase correspondingly. We must question the use of gamma irradiation as there are so many adverse effects and it fails to sterilize the allograft as required.

Also, the sterilization effectiveness against viruses is low (Vangsness et al. 2003). Ethylene oxide sterilization requires strict control of the levels of waste gas in contact with the allograft and is no longer used by tissue banks, due to the possibility of toxic effects for the recipient (dissolution of the graft and articular inflammatory reactions) (Vangsness et al. 2003). The processing techniques used in the preparation and preservation of grafts have been questioned as potentially altering the initial resistance and mechanical properties of the graft prior to implantation.

Two studies carried out in Brazil address the biomechanical properties of patellar and calcaneus tendons of cadavers with the same preparation method as that used in our study, comparing fresh and cryopreserved allografts (Giovani et al., 2006; Reiff et al., 2007). They found no differences. A study on metric measurements and attachment levels of the medial patellofemoral ligament shows this to be a distinct structure (Zimmerman et al., 1994). Although there have been studies on the biomechanical behavior of tendons, the literature does not address histological changes of tendons cryopreserved at $-80^{\circ} \mathrm{C}$ under aseptic conditions (Pearsall et al., 2003). During cryopreservation at $-80^{\circ} \mathrm{C}$, thedestruction of the allograft enzyme appears to be minimal and at least one enzyme, collagenase, which can destroy the tissue, is inactive (Tomford, 1997). Furthermore, with cryopreservation there is no intracellular free water, which is thought to be necessary for enzymatic activity, bacterial proliferation and lipid oxidation (Galea \& Keamey, 2005; Laitinien et al., 2006). Lipid oxidation inside the tissues induces apoptosis and inhibits cell differentiation; such oxidation 
can be minimized or avoided with cryopreservation at temperatures of at least $-70^{\circ} \mathrm{C}$ (Laitinien et al., 2006). The literature refers to histological changes due to cryopreservation only in cartilage (one of the most commonly used grafts in surgical practice), concluding that during freezing, the vitality of the cells is threatened (Schchar \& McGann, 1986). Other injuries may also occur, such as the formation of extracellular ice crystals, intracellular ice nucleation, collapse of the matrix, and breakage of intercellular bridges.

In our study, the histological study of one tendon (not cartilage) was carried out, and none of these histological phenomena were observed with cryopreservation at $-80^{\circ} \mathrm{C}$. Freezing with liquid nitrogen at $-179^{\circ} \mathrm{C}$ has also been used as a storage method with similar results but higher cost (Zimmerman et al., 1994). Another widespread storage method is lyophilization. Cryopreservation and lyophilization have been related to a reduction in allograft antigenicity (Jackson et al., 1990). The use of chilled saline solution is not a guaranteed method because the stock can only be kept safely for short periods (Zimmerman et al., 1994). Treatment with paraformaldehyde and fixation with glutaraldehyde are no longer recommended because of the toxicity of these solutions to the recipient tissue.

We recently published a study in which we proved the histological properties of the flexor tendons of the knee from cadavers subjected to cryopreservation and experience with the use of allografts of the Knee Group from IOT (Bitar et al., 2010; Damasceno et al., 2009).

\section{Cryopreservation: Our method}

\subsection{Tendinous tissue removal}

The attainment of the musculoskeletal tissues has as its source deceased donors with brain death reported by the Committees Intra-hospital - CIHDOTs, Organ Procurement Organizations - OPOS and by the twenty-three central of notification and collection of organs and tissues - CNCDOs, logistically spread throughout country. Notifications for teams pickups are made after the execution of a series of procedures and tests that aim beyond the evidence of brain death, family consent of the donation of organs and tissues.

The donor selection follows a rigorous research with control antigen and antibody serology for HIV, Hepatitis A, B and C, HTLV-1 and 2, syphilis, Chagas disease, toxoplasmosis and cytomegalovirus in addition to testing of last generation for evidencing of DNA (Nucleic Acid Amplification - NAT) for HIV and Hepatitis B and C, required of musculoskeletal tissues. The capture of musculoskeletal tissues (bone and tendons) is performed after the initial screening of donors of multiple organs and tissues (heart, kidney, liver, pancreas, lung, cornea, etc.).

In our specific field, we follow a protocol of evaluation of the donor that counts with a written anamnesis of a term to capture and physical examination. Are excluded donors with orthopedic disorders such as osteoporosis, osteonecrosis, rheumatoid arthritis, lupus erythematosus, malignancy, age that compromises characteristic of tissues, blood transfusion, tattoos or adornments (piercings) within the window period, users of illicit drugs, permanence in endemic areas, generalized or localized infections, fractures, bruises on the limbs which are absorbed in the musculoskeletal tissues or any other situation that would call into doubt the quality of these tissues, as arranged in the existing laws. The tissues removed are immediately packed in triple enclosures, hermetically sealed and sent under refrigeration $\left(-4^{\circ} \mathrm{C}\right)$ to the Tissue Bank. 
A very important step of the process of capture is the reconstruction of the donor and for this matter we use prosthesis specially designed using plaster, wire suture, gauze. This reconstruction is done rigorously and is characterized as the most laborious phase of the procedure. All anatomical parameters are respected, and therefore the deformation of the donor does not occur (Figures 1 and 2).

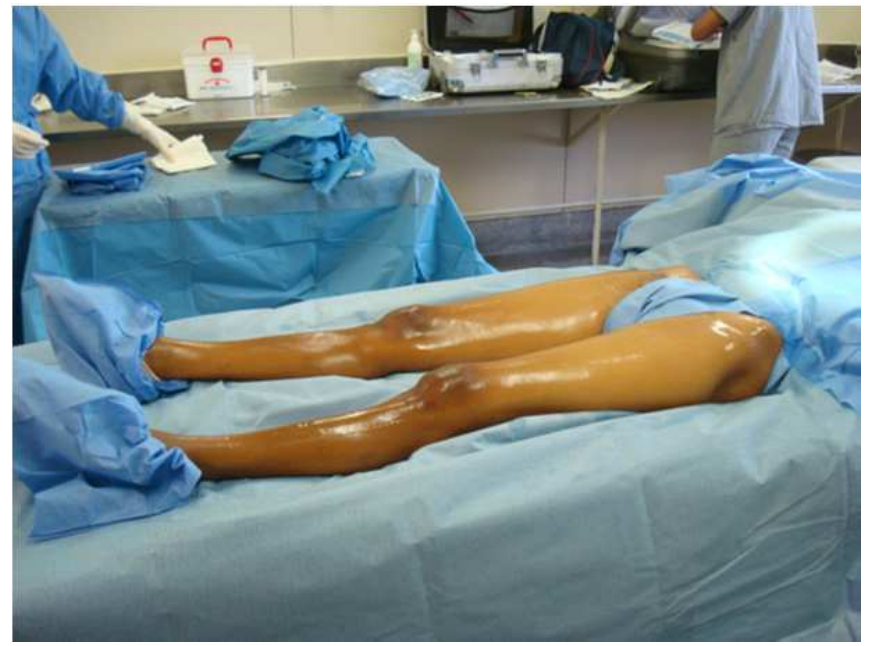

Fig. 1. Pre-operative preparation of the potential musculoskeletal tissues doner.

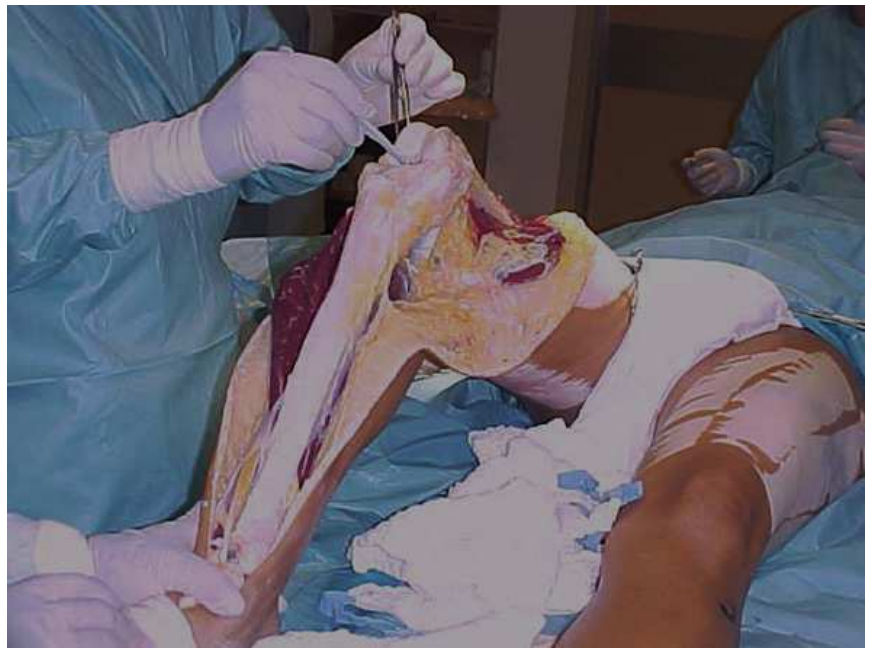

Fig. 2. Tissue removal: bone and tendon dissecation under asseptic conditions.

\subsection{Processing and cryopreservation of musculoskeletal tissues}

At the end of the uptake, the tissues are sent to BTME chilled in coolers with temperature monitoring throughout the period of transportation. The processing step is preceded by a 
planning of activities needed for its implementation, such as provision of materials and instruments, convocation of the processing team, definition of preparation and dimensioning according to the need for service (queue) requests from orthopedic and dental surgeons. This step is performed in the operating room properly rated (class 100 or ISO 5) equipped with integrated laminar flow (Figure 3). The room also has an antechamber and pass-through and all environments have strict control of air particles and positive pressure for quality assurance of tissues processed there.

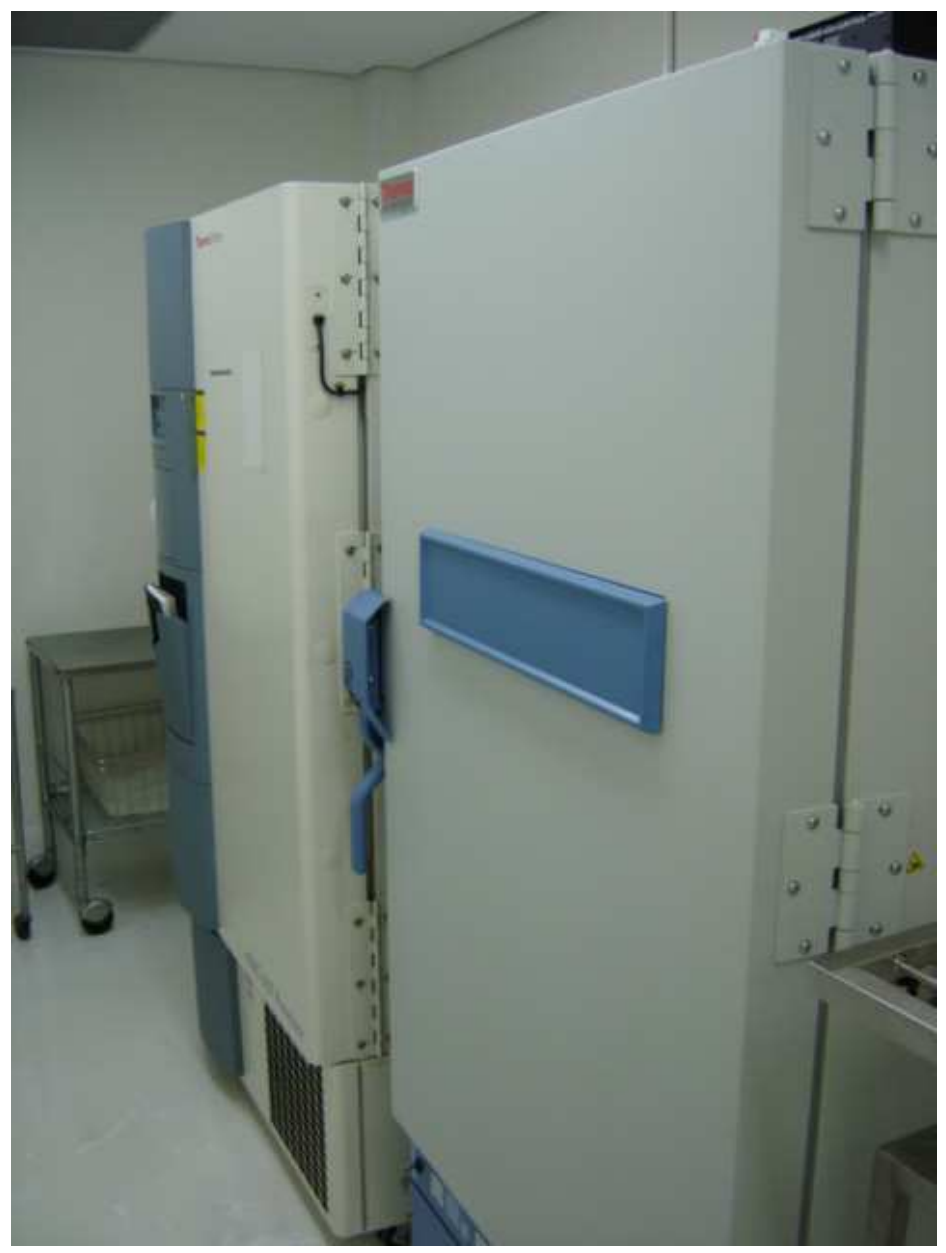

Fig. 3. Tissue cryopreservation área. Ultrafreezer with a temperature of $-80^{\circ} \mathrm{C}$.

In addition, specific attire is required of the professional team that should only use nonwoven clothes to avoid dispersion of particles that emit the cotton clothes (Figure 4). Not only the non-woven attire is required but the team's behavior should be differentiated. Thus, sudden movements, use of cosmetics and hair exposure should be avoided during the permanence in this room. Ensuring an appropriate approach is not only a result of training 
of the nursing staff that performs the procedure, but also other professionals who access the environment (cleaning maintenance).

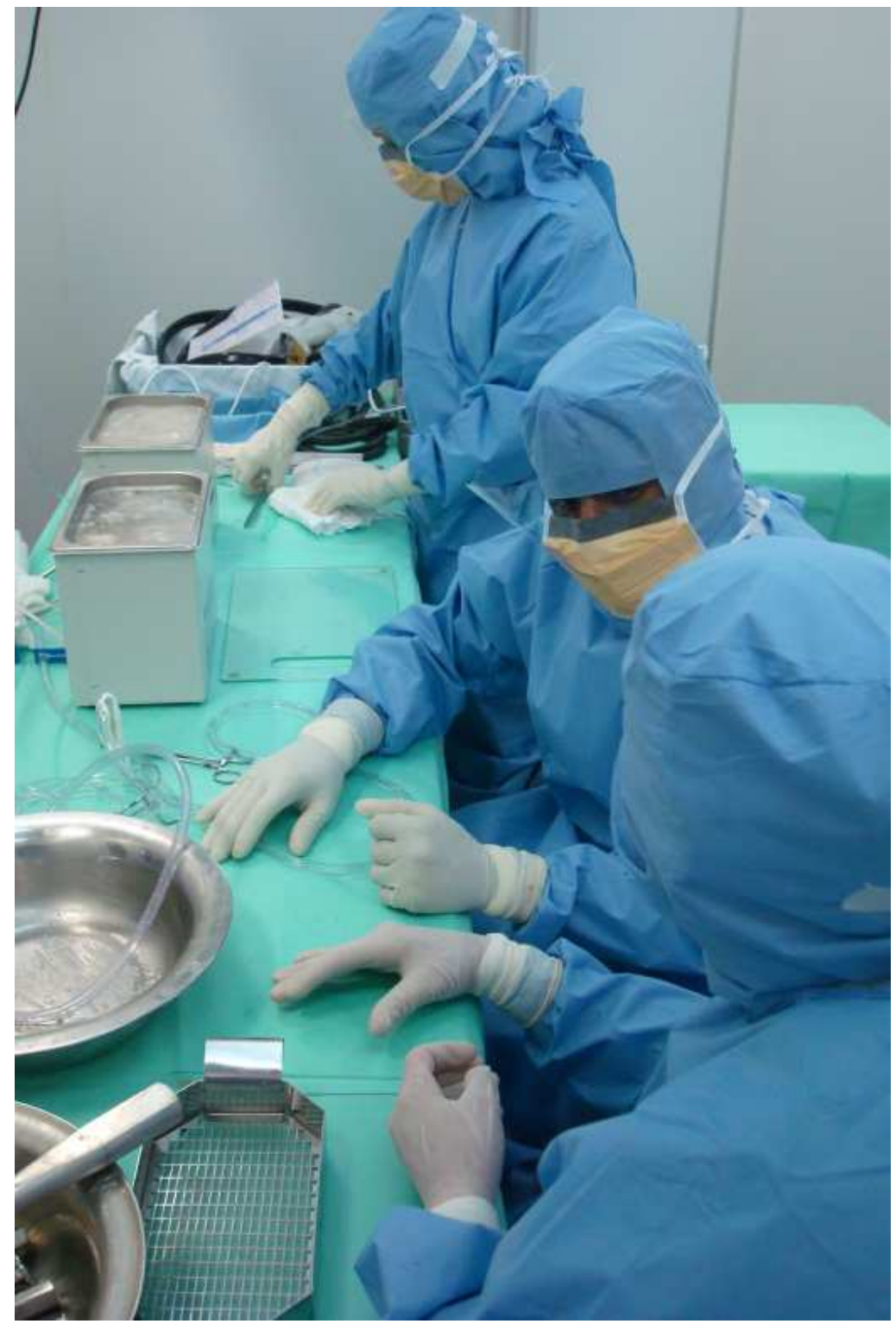

Fig. 4. Processing team in activity in the controlled área (ISO 5: Class 100).

The BTME conducts various types of processing of these tissues with the purpose to use in orthopedic and dental surgeries, each of which requires a specific plan. For the processing of fresh frozen tissues it is performed what we call mechanical processing, ie removal of 
adventitial tissue such as blood, periosteum, subcutaneous tissue, muscle, fascia and fibrotic tissue. Then, these tissues are immersed in emulsifying solutions based on hydrogen peroxide and alcohol under ultrasonic agitation (Figure 5).

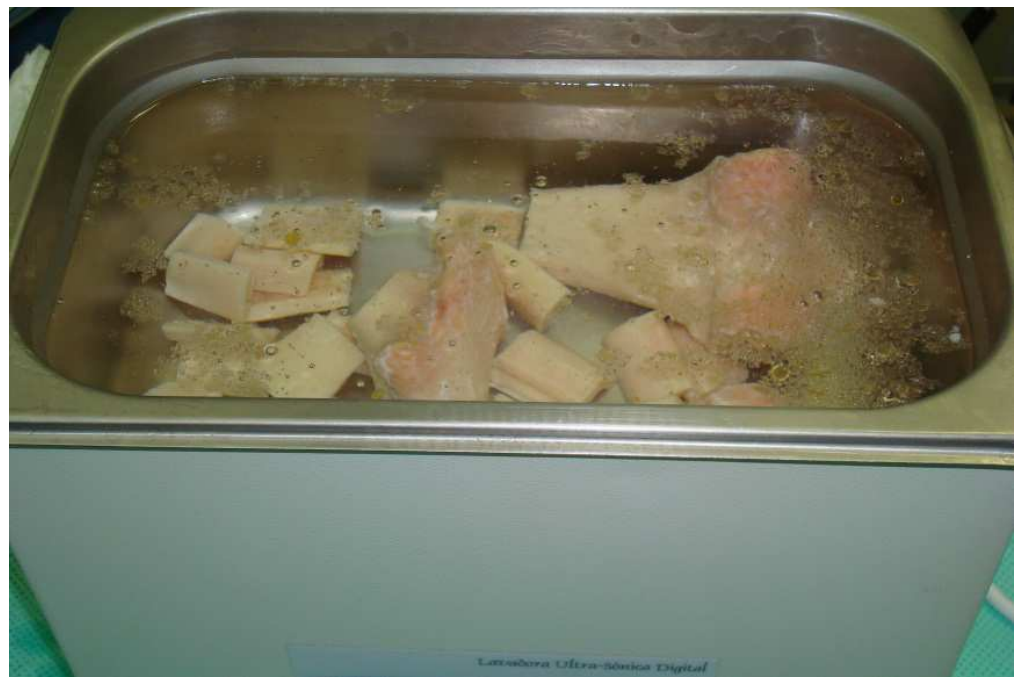

Fig. 5. Tissue's chemical processing. Ultrasonic clining with emulsifying solution.

Then, a sampling of these resultant solutions, of bone marrow of long bones and fragments of each tissue processing are subjected to microbiological examination (General Knowledge, and Culture of Anaerobic Fungi). Furthermore, it is also obtained samples to histopathological analysis.

Finally starts the procedure of packaging of all the processed grafts which are measured (length, height, weight, volume, perimeter) and kept in sterile triple wrappers, vacuum sealed and properly identified as tissue in analysis. The label contains information from the donor, examination, lot number, item, expiration date, type of conservation and barcode.

Once all the tissues are identified, they are x-rayed at the very BTME and referred to cryopreservation.

The bones can also be processed in its lyophilized form, where all water is removed with the tissue still frozen. The process involves placing the tissue in a lyophilizer chamber where ice crystals sublimate by the action of the high pressure, not passing through the liquid phase and thus maintaining the viability of bone matrix. The result is a dry tissue, conservable at room temperature that must receive final sterilization by irradiation.

At the end of the processing it is performed the documentation of the procedure in the Processing and archived in the donor's chart. The stock of tissues can be kept either frozen or dried, if necessary, according to the same standards used by the Global Association of Tissue Banks . Other forms of processing have been investigated in order to reduce costs related to storage and maintenance. The glicerolization of bone tissue is presented as a processing methodology capable of maintaining the viability of the matrix and prevent bacterial growth, and allows storage at room temperature (Giovani et al., 2006). 


\subsection{Tissue cryopreservation}

In the room of cryopreservation tissues are stored according to their status in the process. Thus, there is a space for tissues in analysis or in quarantine (where they remain for about 60 days until the results of all examinations) and those already released for use. Both rooms are equipped with ultrafreezers with temperatures ranging from 85 to 110 degrees below zero (Amatuzzi et al., 2000).

The room is also equipped with air-conditioning system, own power generator and the unfreezing protection of carbon dioxide ( $\mathrm{CO} 2$ Backup), and a rigorous system of monitoring the temperature, with printed record of temperature for 24 hours and alarm system via satellite, which guarantees the right temperature and early detection of complications.

Depending on the outcome of the analysis, the tissues are transferred to the room of material released for use. The maximum period of cryopreservation is five years to bone tissue and two years for soft tissues and tendons.

\subsection{Quality control and distribution}

By the time of transplantation, all tissues processed are subjected to rigorous quality assurance criteria. It requires the evaluation of all data pertinent to the donor, test results, maintenance and control of equipment, materials and instruments used in all phases of each procedure (Figures 6 and 7).

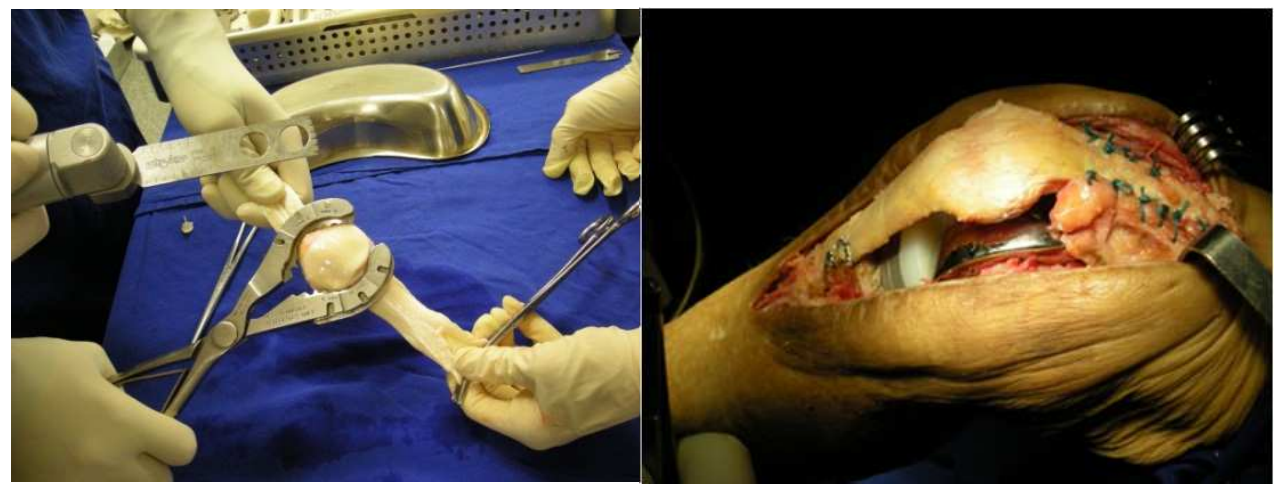

Fig. 6. and 7. Patellar tendon allograft transplant.

All processes are computerized through the System Manager of the Tissue Bank, a program designed to record all the steps which allows the rescue and traceability of each graft processed and delivered. Through a coding is possible to identify the donor, lot, expiration, and status of the tissue examination (under review, released, deleted and used).

Given the need of retrieval of information, as the evidence of an adverse effect, you can quickly and safely obtain the information and implementation of corrective and preventive actions.

For a lot of graft in analysis to be released for use nurses must analyze the results of all tests performed: NAT serology or PCR for HIV, HBC and HCV, General Culture, Anaerobic Culture and Culture of Fungi, pathology reports and radiographic findings. These reports of 
examinations are assessed and ultimately released by the Technical Director of the Tissue Bank.

Besides examinations, evaluation of the printed record of temperature during the storage period is considered. The temperature oscillations are quickly detected and reported to the team members from the BTME even remotely by cell phones. In addition, audible alarms at strategic points in the hospital and the presence of $\mathrm{CO} 2$ backups, ensure system reliability.

After the release of each lot, the nurses carry a detailed examination of integrity of each tissue during the replacement of tissues in analysis labels to released labels and posterior transfer of the sector. The logistics of storage of tissues in ultrafreezers considers the type of tissue and speed up the search.

We emphasize that for a rigorous quality control all steps of each procedure are carried out through check-lists with double checking and approval.All relevant data of the donor or lot records are filed in a single file and stored at the BTME for a minimum of 25 years.

A serum bank with plasma samples of donors are offered by BTME if necessary examination of counterproof.

\section{Our experience}

In the last five years, we have performed 35 knee ligament reconstructions, including multiple ligament, and isolated ACL and PCL reconstructions with single and double bundle techniques, and ACL reviews. Twenty seven men and eight women underwent surgery with the employment of the following grafts from the tissue bank: anterior tibial tendon (48 units), patellar tendon (4 units), quadriceptal tendon (5 units), semitendinosus tendon ( 4 units), calcaneus tendon ( 1 units) and fibular tendon ( 1 units). The patients followup range from 6 to 57 months and we are still collecting data from this cases. Our first results showed that there no viral or bacterial infection associated to the use of allografts in any of the cases or other complications, and clinical outcome of these patients has shown good results with the use of tendons from the tissue bank.

A study conducted in another service, in which we colaborate, revised the records of 46 patients who were submitted to ligament reconstructions between 1999 and 2007 using grafts supplied by the same tissue bank (Damasceno et al., 2009). Thirty-four male patients and 12 female patients were reviewed, with follow-up time ranging from 10 months to 9 years (mean: 3.1 years).The surgical procedures used 9 units of patellar tendons, 9 units of anterior tibial tendons, 8 units of calcaneal tendons, 6 units quadriceptal tendons and 1 unit of fibular tendon, mainly for multiple ligamentar reconstructions and ACL reviews ${ }^{41}$. There were also no viral or bacterial infection cases ${ }^{41}$.

The decrease in morbidity and postoperative complications allied to good results obtained in our samples reinforces the idea that the use of allografts is a good and safe option in knee ligament reconstruction.

\section{References}

Albert, A; Leemrijse, T; Druez, V; Delloye, C; Cornu, O. (2006) Are bone autografts still necessary in 2006? A three-year retrospective study of bone grafting. Acta Orthop Belg, 72, 734-40. ISSN 0001-6462. 
Amatuzzi, MM; Croci, AT; Giovani, AMM; Santos, LAU. (2000) Banco de tecidos: estruturação e normatização. [Tissue bank: structure and organization]. Rev Bras Ortop, 35, 165-72. ISSN 0102-3616.

Barrios, RH; Leyes, M; Amillo, S; Oteiza, C. (1994) Bacterial contamination of allografts. Acta Orthop Belg, 60, 293-5.

Bitar, AC; Santos, LAU; Croci, AT; Pereira, JARM; França Bisneto, EM; Giovani, AMM; Oliveira, CRGCM. (2010) Histological Study of Fresh versus Frozen Semitendinous Muscle Tendon Allografts. CLINICS, 65(3),297-303 ISSN 1807-5932.

Chang, SK; Egami, DK; Shaieb, MD; Kan, DM; Richardson, AB. (2003) Anterior cruciate ligament reconstruction: allograft versus autograft. Arthroscopy, 19, 453-62. ISSN 0749-8063.

Costic, RS; Labriola, JE; Rodosky, MW; Debski, RE. (2004) Biomechanical rationale for development of anatomical reconstructions of coracoclavicular ligaments after complete acromioclavicular joint dislocations. Am J Sports Med, 32, 1929-36. ISSN 1552-3365.

Curran, AR; Adams, DJ; Gill, JL; Steiner, ME; Scheller, AD. (2004) The biomechanical effects of low-dose irradiation on bone-patellar tendon-bone allografts. Am J Sports Med, 32, 1131-1135. ISSN 1552-3365.

Damasceno, ML; Ferreira, TF; D’Elia, CO; Demange, MK; Pécora, JR; Hernandez, AJ; Camanho, GL; Croci, AT; Santos, L; Helito, CP. (2009) Use of Allograft in Ligamentar Reconstruction of Knee. Acta Ortop Bras, 17(5), 265-8 ISSN 2176-7521.

Fideler, BM; Vangsness, CT Jr; Lu, B; Orlando, C; Moore T. (1995) Gamma irradiation: effects on biomechanical properties of human bone-patellar tendon-bone allografts. Am J Sports Med, 23, 643-646. ISSN 1552-3365.

Flahiff, CM; Brooks, AT; Hollis, JM; Vander Schilden, JL; Nicholas, RW. (1995) Biomechanical analysis of patellar tendon allografts as a function of donor age. Am J Sports Med, 23, 354-8. ISSN 1552-3365.

Galea, G; Kearney, JN. (2005) Clinical effectiveness of processed and unprocessed bone. Transfus Med. 15:165-74.

Giovani, AM; Croci, AT; Oliveira, CR; Filippi, RZ; Santos, LA; Maragni, GG. (2006) Comparative study of cryopreserved bone tissue and tissue preserved in a $98 \%$ glycerol solution. CLINICS, 61, 565-70. ISSN 1807-5932.

Grieb, TA; Forng, RY; Bogdansky, S. (2006) High-dose gamma irradiation for soft tissue allografts: high margin of safety with biomechanical integrity. J Orthop Res, 24, 1011-1018. ISSN 0736-0266.

Inclan A. (1942) The use of preserved bone graft in orthopaedic surgery. J Bone Joint Surg Am, 24, 81-96.

Jackson, DW; Corsetti, J; Simon TM. (1996) Biologic incorporation of allograft anterior cruciate ligament replacements. Clin Orthop, 324, 126-33.

Jackson, DW; Windler, GE; Simon, TM. (1990) Intraarticular reaction associated with the use of freeze-dried, ethylene oxide-sterilized bone-patella tendon-bone allografts in the reconstruction of the anterior cruciate ligament. Am J Sports Med, 18, 1-10. ISSN 1552-3365.

Laitinen, M; Kivikari, R; Hirn M. (2006) Lipid oxidation may reduce the quality of a freshfrozen bone allograft. Is the approved storage temperature too high? Acta Orthop, 77, 418-21. ISSN 1745-3674.

Lawhorn, KW; Howell, SM. (2003) Scientific justification and technique for anterior cruciate ligament reconstruction using autogenous and allogenic soft-tissue grafts. Orthop Clin North Am, 34, 19-30. ISSN 0030-5898. 
Levitt, RL; Malinin, T; Posada, A; Michalow, A. (1994) Reconstruction of anterior cruciate ligaments with bone-patellar tendon-bone and achilles tendon allografts. Clin Orthop Relat Res, 303, 67-78. ISSN 0009-921X.

Marrale, J; Morrissey, MC; Haddad, FS. (2007)A literature review of autograft and allograft anterior cruciate ligament reconstruction. Knee Surg Sports Traumatol Arthrosc, 15, 690-704. ISSN 0942-2056.

Nutton, RW; McLean, I; Melville, E. (1999) Tendon allografts in knee ligament surgery. J R Coll Surg Edinb, 44, 236-40.

Papandrea, P; Vulpiani , MC; Ferretti, A; Conteduca, F. (2000) Regeneration of the semitendinosus tendon harvested for anterior cruciate ligament reconstruction. Evaluation using ultrasonography. Am J Sports Med, 28, 556-61. ISSN 1552-3365.

Pearsall, AW; Hollis, JM; Russell, GV Jr; Scheer, Z. (2003) A biomechanical comparison of three lower extremity tendons for ligamentous reconstruction about the knee. Arthroscopy, 19, 1091-6. ISSN 0749-8063.

Rappe, M; Horodyski, M; Meister, K; Indelicato, PA. (2007) Nonirradiated versus irradiated Achilles allograft: in vivo failure comparison. Am J Sports Med, 35, 1653-1658. ISSN 1552-3365.

Reiff, RBM; Croci, AT; Bolliger Neto, R; Pereira, CAM. (2007) Estudo comparativo de propriedades biomecânicas da porção central do tendão calcâneo congelado e a fresco. [Comparative study on biomechanical properties of the central portion of frozen and fresh calcaneus tendon]. Acta Ortop Bras, 15, 6-8. ISSN 2176-7521.

Schachar, NS; McGann, LE. (1986) Investigations of low-temperature storage of articular cartilage for transplantation. Clin Orthop Relat Res, 146- 50. ISSN 0009-921X.

Sherman, OH; Banffy, MB. (2004) Anterior cruciate ligament reconstruction: which graft is best? Arthroscopy, 20, 974-80. ISSN 0749-8063.

Sterling, JC; Meyers, MC; Calvo RD. (1995) Allograft failure in cruciate ligament reconstruction. Follow-up evaluation of eighteen patients. Am J Sports Med, 23, 1738. ISSN 1552-3365.

Sun, K; Zhang, J; Wang, Y; Xia, C; Zhang, C; Yu, T; Tian, S. (2011) Arthroscopic Reconstruction of the Anterior Cruciate Ligament With Hamstring Tendon Autograft and Fresh-Frozen Allograft A Prospective, Randomized Controlled Study. Am J Sports Med. [Epub ahead of print] ISSN 1552-3365.

Tomford, W. Transmission of disease through musculoskeletal transplantation. Portland Bone Symposium. Portland: Oregon Health Sciences University, 1997.

Urabe, K; Itoman, M; Toyama, Y; Yanase, Y; Iwamoto, Y; Ohgushi, H. (2007) Current trends in bone grafting and the issue of banked bone allografts based on the fourth nationwide survey of bone grafting status from 2000 to 2004. J Orthop Sci, 12, 520525. ISSN 1436-2023.

Vangsness, CT Jr; Garcia, IA; Mills, CR; Kainer, MA; Roberts, MR; Moore, TM. (2003)Allograft transplantation in the knee: tissue regulation, procurement, processing, and sterilization. Am J Sports Med, 31,474-481. ISSN 1552-3365.

Zimmerman, MC; Contiliano, JH; Parsons, JR; Prewett, A; Billotti, J. (1994) The biomechanics and histopatology of chemically processed patellar tendon allografts for anterior cruciate ligament replacement. Am J Sports Med, 22, 378-386. ISSN 1552-3365. 


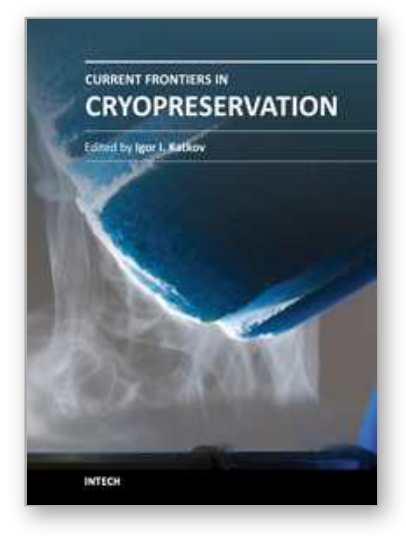

\author{
Current Frontiers in Cryopreservation \\ Edited by Prof. Igor Katkov
}

ISBN 978-953-51-0302-8

Hard cover, 462 pages

Publisher InTech

Published online 14, March, 2012

Published in print edition March, 2012

Almost a decade has passed since the last textbook on the science of cryobiology, Life in the Frozen State, was published. Recently, there have been some serious tectonic shifts in cryobiology which were perhaps not seen on the surface but will have a profound effect on both the future of cryobiology and the development of new cryopreservation methods. We feel that it is time to revise the previous paradigms and dogmas, discuss the conceptually new cryobiological ideas, and introduce the recently emerged practical protocols for cryopreservation. The present books, "Current Frontiers in Cryobiology" and "Current Frontiers in Cryopreservation" will serve the purpose. This is a global effort by scientists from 27 countries from all continents and we hope it will be interesting to a wide audience.

\title{
How to reference
}

In order to correctly reference this scholarly work, feel free to copy and paste the following:

Alexandre C. Bitar, Caio Oliveira D'Elia, Antônio Guilherme P. Garofo, Wagner Castropil, Luiz Augusto U. Santos, Marco K. Demange, José Ricardo Pécora and Alberto T. Crocci (2012). Cryopreservation - A Viable Alternative in Preparation for Use of Allografts in Knee Ligament Reconstruction, Current Frontiers in Cryopreservation, Prof. Igor Katkov (Ed.), ISBN: 978-953-51-0302-8, InTech, Available from: http://www.intechopen.com/books/current-frontiers-in-cryopreservation/a-viable-alternative-in-preparation-foruse-of-allografts-in-knee-ligament-reconstruction-

\section{INTECH}

open science | open minds

\section{InTech Europe}

University Campus STeP Ri

Slavka Krautzeka 83/A

51000 Rijeka, Croatia

Phone: +385 (51) 770447

Fax: +385 (51) 686166

www.intechopen.com

\section{InTech China}

Unit 405, Office Block, Hotel Equatorial Shanghai

No.65, Yan An Road (West), Shanghai, 200040, China

中国上海市延安西路65号上海国际贵都大饭店办公楼 405 单元

Phone: +86-21-62489820

Fax: $+86-21-62489821$ 
(C) 2012 The Author(s). Licensee IntechOpen. This is an open access article distributed under the terms of the Creative Commons Attribution 3.0 License, which permits unrestricted use, distribution, and reproduction in any medium, provided the original work is properly cited. 